NEWS

LHC meltdown before first collision

A mechanical failure has shut down the world's largest particle accelerator for at least two months.

The Large Hadron Collider (LHC), a US\$4.1-billion machine located at CERN, Europe's particle-physics laboratory near Geneva, Switzerland, will be out of commission possibly until early next year to allow repairs to be made to a section of superconducting cable that is thought to have melted during a test on 19 September, just nine days after the collider circulated its first beams.

"We've had better days," says James Gillies, CERN's chief spokesperson.

The LHC is designed to accelerate protons to energies of 7 teraelectronvolts before smashing them together. To keep the beam focused and fast, the machine depends on around 9,600 superconducting niobium-titanium magnets. The magnets must be kept at temperatures of just 1.9 kelvin while carrying roughly 10,000 amps. The magnets carry this enormous load without generating heat, but if a section of the niobium-titanium rises above its operating temperature it can lead to a catastrophic failure known as a 'quench'.

That is exactly what seems to have happened as physicists passed 8,000 amps into a sector of the LHC's 27-kilometre underground ring. A cable feeding current between two of the LHC's

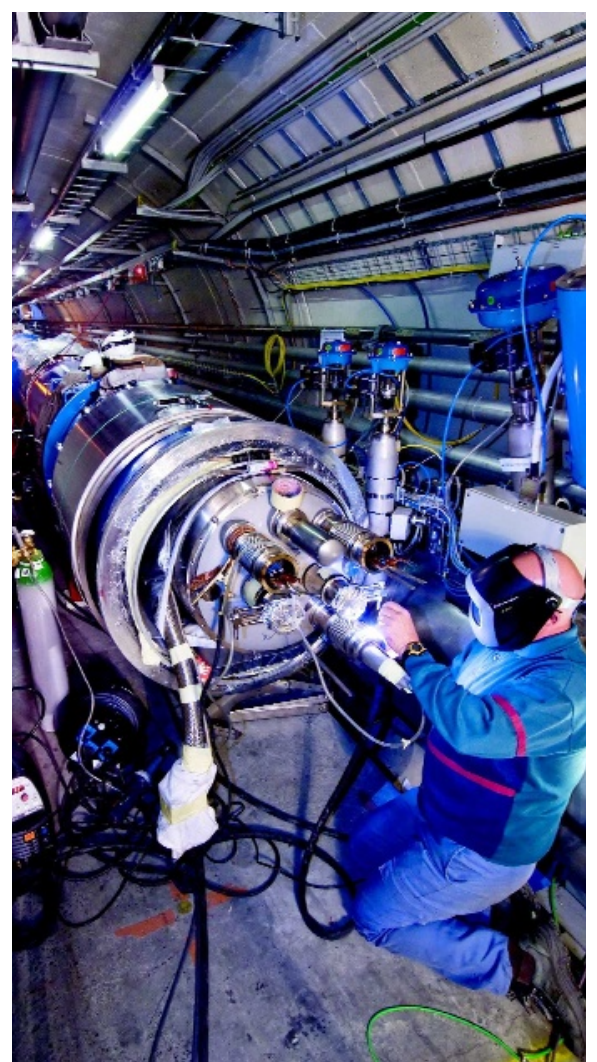

The shutdown may be due to a welding failure. beam-focusing quadrupole magnets suddenly z heated to above superconducting temperatures and melted. The failure seems to have hap- $\frac{\mathrm{o}}{\mathrm{\alpha}}$ pened at a joint where two sections of cable $\Sigma$ were spliced together. Tens of thousands of joints run around the LHC and many of them had already been tested without incident.

The failure caused the liquid helium that was being used to cool the magnets to boil off, apparently rupturing the machine and releasing as much as a tonne of the gas into the LHC tunnels. During testing the tunnels are evacuated and no injuries were reported.

Such failures are not uncommon during the early commissioning of an accelerator, Gillies says. "With a normally conducting machine you could fix it in a couple of days." But the LHC's superconducting status also makes it difficult to service. To fix the broken sector, physicists must heat thousands of tonnes of magnets from near-absolute-zero to room temperature, make the necessary repairs, and then slowly cool the system back down. Just warming and cooling will take at least two months, Gillies says.

The setback has dashed the hopes of thousands of researchers working on the four main detectors that will use the LHC. They had hoped to get their first data from proton-proton collisions as early as this week, but it now

\title{
California institute to help stem-cell biotechs
}

The California Institute for Regenerative Medicine (CIRM) is launching a loan programme that aims to help private biotechnology companies while providing a funding stream for the institute. The programme is expected to be approved this week by the board that oversees CIRM, although major specifics are still undecided, including the amount of money involved.

The loans are intended to help companies bring stem-cell discoveries to the clinic. It should also foster a closer relationship between California's biotech industry and the institute, which was created in 2004. Although CIRM has approved more than $\$ 614$ million in grants since its inception, only one of those has gone to a company.

CIRM's could prove the biggest

US state-funded biotechnology loan programme. Global accounting firm PriceWaterhouseCoopers has calculated that the institute stands to make at least $\$ 100$ million over an 8- to 10 -year programme, assuming that it issues loans totalling $\$ 500$ million to $\$ 700$ million. At a meeting on 20 September, a subcommittee of the institute's board discussed a $\$ 500$ million figure for the programme. That would nicely stretch CIRM's reserves over the \$3-billion, 10-year lifespan approved by voters.

The loans are intended to help companies cross regions of the "valley of death" that stops many promising ideas from making it to the clinic, says Duane Roth, chief executive of the San Diego-based businessdevelopment organization CONNECT, who headed the loan-policy task force.

"It's for after the research grant, where you have really exciting information but a lot of work to do to make it to the point where you can get traditional funders, such as venture capital and venture debt to invest," Roth says.

Few companies are trialling therapies made from stem cells yet. One, StemCells in Palo Alto, California, is testing neural stem cells derived from fetal tissue in children with the fatal genetic condition Batten disease (see Nature doi:10.1038/ news 060703-3; 2006). The company enrolled six children in the trial, but one of them died in January from the illness, according to the company. Geron in Menlo Park, California, has plans to test cells derived from embryonic stem cells in patients with spinal-cord injury, but in May the US Food and Drug Administration delayed the trial.

That raises the question of how comfortable the public will be with committing CIRM funds to one of the riskiest fields of a risky sector. Two types of loan will be awarded - recourse loans, 
seems unlikely that collisions will occur this year. CERN normally shuts down during the winter months to save on electricity costs, says Tommaso Dorigo, a physicist at the CERN's Compact Muon Solenoid detector. He and others think the repairs will run into that winter shutdown. "I'm not sure collisions are going to happen in 2008," Dorigo says.

That doesn't mean physicists will be sitting on their hands in the coming months. Much must still be done to prepare the detectors for first collisions, according to Pauline Gagnon, a senior scientist on CERN's ATLAS detector. Physicists must still calibrate the hundreds of thousands of sub-detectors in each of the larger experiments, and that can be done with high-energy cosmic rays from outer space rather than beam from the machine. "It would be easier with the beam, but we can still do it," Gagnon says.

But for graduate students trying to complete their theses, there is no substitution for the real thing. Fresh data are imperative, especially for the American contingent, according to Seth Zenz, a graduate student at the University of California, Berkeley, who is currently working on ATLAS. Without new data, Zenz explains, he can't complete his thesis, and he is now planning on spending seven years in graduate school instead of six. Still, Zenz says, he's willing to put up with the delays: "I can wait a few more months before getting back to affordable sushi and burritos in California," he says.

Geoff Brumfiel

which must be paid back, and non-recourse loans, which do not have to be paid back if a product's development ends. CIRM is guaranteed a stake in the recipient company worth $10 \%$ of the loan's value for a recourse loan, or $100 \%$ for a non-recourse loan. The loans come with other strings - for instance, a requirement to provide California with any developed product at a state-approved price.

Greg Bonfiglio, managing partner of Palo Alto-based Proteus Venture Partners, which focuses on regenerative medicine, estimates that roughly 700 companies around the world are working in the field, and many are in California, where the loan funds must be spent. So there is already a market for the loans, he says.

What will determine biotech's response — and CIRM's potential windfall - will be their assessment of the trade-offs involved in accepting CIRM money: "It's really about the terms - that's where the rubber meets the road," Bonfiglio says.

Erika Check Hayden

\section{Monoclonal antibodies come of age}

A fast way of isolating antibodies from people has been used to create a library of the immune proteins produced by someone inoculated with a nicotine-acting vaccine. Roger Beerli and his team at Cytos Biotechnology in Schlieren, Switzerland, used lymphocytes from an individual who was enrolled in a clinical trial of the smokingcessation vaccine, and with their technique rapidly identified nicotine-specific antibodies ${ }^{1}$.

The work is the latest offering in a burgeoning field of therapeutics: monoclonal antibodies. These antibodies are derived from a single population of cells and bind to their target at a specific site. Last month, researchers reported that they had isolated functional antibodies from survivors of the 1918 influenza pandemic ${ }^{2}$, and in April, another team reported the rapid cloning of influenza antibodies from people who had recently been vaccinated against the disease ${ }^{3}$. Researchers hope the findings will eventually lead to 'passive immunity' treatments.

The market for monoclonal antibodies is the fastest-growing segment of the pharmaceutical industry. In 2007, therapeutic monoclonal antibodies brought in more than US\$26 billion, most of which came from treatments for cancer and autoimmune diseases. That same year, 50 companies had anticancer antibodies in clinical trials worldwide ${ }^{4}$.

The field has come a long way since preantibiotic days when infected patients were injected with a serum of horse antibodies from an animal that had been exposed to the same disease. Such treatments carried a high risk of serum sickness caused by immune reactions to the horse proteins. When small-molecule antibiotics emerged on the scene, animal serum therapies were largely abandoned.

Recent advances in antibody harvesting are breathing new life into the idea of passiveimmunity therapy, this time with human antibodies. "Infectious-disease research has come full circle," says Andrew Chan, senior vice-president of immunology and antibody engineering at Genentech, a biotechnology company in South San Francisco, California.

The fundamental techniques for making monoclonal antibodies were laid down years ago, but as the market for monoclonal antibodies grows, companies are modifying those techniques to overcome technical difficulties and to establish a hold in a crowded patent landscape. "Small biotechnology companies are trying to figure out new ways to work around existing intellectual property," says immunologist James Crowe of Vanderbilt
University Medical Center in Nashville, Tennessee. "That gives them a high incentive to be innovative."

Isolating antibodies from immunized humans has its limits, however. "The key is that you have to start with a disease that you can immunize people against," says Crowe. Researchers cannot, for example, immunize patients against cancer or infectious diseases for which there is no approved vaccine. And, Crowe adds, "You're not going to immunize someone against the 1918 flu". However, people who were exposed to it but survived because of their own natural antibody response might have antibodies effective against future, similar strains. Other researchers have isolated antibodies from survivors of H5N1 avian flu ${ }^{5}$.

In theory, such antibodies could be tested for use as therapies, but antibodies are much more difficult and expensive to produce than small molecules. At present, there is only one available targeted antibody therapy against an infectious disease Medlmmune's palivizumab, used to fend off respiratory syncytial virus in premature infants. Palivizumab brings in more than a billion

dollars a year for the biotech company, based in Gaithersburg, Maryland, but few other infectious diseases are expected to be so lucrative.

The high specificity of an antibody is a valued asset in the clinic, but can be detrimental in the fast-changing world of infectious disease, in which viruses such as HIV can mutate out of an antibody's grasp. "We're seeing a little bit of rediscovering large molecules like monoclonal antibodies for infectious diseases," says Chan. "But it's still quite limited."

Some companies may be wary of trialling monoclonal antibody therapies after a trial in 2006 by the now-defunct German company TeGenero in which six healthy volunteers were left fighting for their lives. But the drug (TGN1412) the six took was unusual in that it activated immune cells rather than inhibiting them.

Human-produced antibodies could also be used as a research tool, says Antonio Lanzavecchia of the Institute for Research in Biomedicine in Bellinzona, Swizerland. "I really believe this approach is going to be the major pathway to new vaccines," he says. Heidi Ledford

1. Beerli, R. R. et al. Proc. Natl Acad. Sci. USA 105, 14336-14341 (2008).

2. Yu, X. et al. Nature doi:10.1038/nature07231 (2008).

3. Wrammert, J. et al. Nature 453, 667-671 (2008).

4. Reichert, J. M. \& Valge-Archer, V. E. Nature Rev. Drug Discov. 6, 349-356 (2007)

5. Simmons, C. P. et al. PLoS Med. 4, e178 (2007) 